\title{
Palaeoenvironmental control on primary fluids characteristics of lacustrine source rocks in the Autun Permian Basin (France)
}

\author{
Sylvain Garel ${ }^{1,2, *}$, Françoise Behar ${ }^{2}$, Johann Schnyder ${ }^{1}$ and François Baudin ${ }^{1}$ \\ ${ }^{1}$ Université Pierre et Marie-Curie Paris 6, institut des Sciences de la terre de Paris, CNRS UMR 7193, 117, Tour 56-66 5e étage, \\ 4, place Jussieu, 75005 Paris, France \\ 2 Total - Exploration \& Production - Exploration division, 2, place Jean-Millier - La Défense 6, 92078 Paris La Défense cedex, France
}

\begin{abstract}
The Autunian (Late Gzhelian-Sakmarian, 295 Ma) of the Autun Basin (Saône-et-Loire, France) is well known for its lacustrine oil-shales and boghead that were exploited during the 19th and 20th centuries. A study of the kerogen geochemistry, palynofacies, hydrocarbon (HC) distribution of pyrolysates and kinetics on these organic-rich sediments gave indications on the control of lacustrine primary fluid characteristics by palaeoenvironmental settings. Palynofacies results have shown a Botryococcus algae dominance in the boghead, whereas the oil-shales were dominated either by a mixing of terrestrial particles and lacustrine phytoplanktonic/bacterial organic matter (OM), or by a lacustrine OM that suffered biodegradation within the water column. During the Autunian, an increasing trend of degraded lacustrine OM concentration is observed in the successive oil-shales. Geochemical and kinetics analyses showed that, except for the boghead, hydrogen index values were $<700 \mathrm{mg} / \mathrm{g}$ TOC and activation energies diagram showed multi-energetic profiles, unexpected for such a lacustrine OM. Along with pyrolysates primary fluids ones, these results unraveled two groups of oil-shale samples. On the one hand, samples dominated by well-preserved lacustrine and terrestrial OM produced primary fluids dominated by $n$-alkanes with $\left(n-\mathrm{C}_{6^{-}}\right.$ $\left.n-\mathrm{C}_{14}\right) / n-\mathrm{C}_{14+} n$-alkanes ratio depending on the proportion of terrestrial OM. They were only encountered in the three oldest oil-shales. On the other hand, the HC profile of fluids originating from samples dominated by degraded lacustrine OM, which was obtained for the first time in this study, show low $n$-alkanes concentrations and a relatively prominent hump. These samples were only present in the three youngest oilshale levels. Finally, the boghead showed a link between strong concentration of the Pila genus of Botryococcus algae and a primary fluid dominated by $n-\mathrm{C}_{6}-n-\mathrm{C}_{14} n$-alkanes.

By comparing these data with published palaeoenvironmental studies, it appears that the kind of dominant $\mathrm{OM}$, and thus the HC distribution of primary fluids, is controlled by the lake level: a lower depth preventing the settlement of anoxic conditions in the bottom waters, and the subsequent good preservation of the OM. During the Autunian, the lake level decreased, consequence of a reduced tectonic activity and of the beginning of a dryer period. Finally, these changes will have caused a strong decrease of the nutrient influx to the lake, favoring the bloom of Botryococcus algae that accumulated to form the boghead.
\end{abstract}

Keywords: oil-shale / lacustrine environment / Type I kerogen / boghead / primary fluids / organic geochemistry

Résumé - Contrôle paléoenvironnemental des caractéristiques des fluides primaires de roches mères lacustres dans le Bassin permien d'Autun (France). L'Autunien (Gzhélien terminal-Sakmarien $\sim 295 \mathrm{Ma}$ ) du Bassin d'Autun (Saône-et-Loire) est bien connu pour ses niveaux de schistes bitumineux lacustres et son boghead qui furent exploités durant les $19^{\mathrm{e}}$ et $20^{\mathrm{e}}$ siècles. Ces sédiments riches en matière organique ont fait l'objet d'une étude géochimique, cinétique, des palynofaciès et de la distribution des hydrocarbures (HC) des pyrolysats afin d'obtenir des indications sur le contrôle exercé par les conditions paléoenvironnementales sur les caractéristiques des fluides primaires. Les palynofaciès ont montré une dominance d'algues Botryococcus dans le boghead, tandis que les schistes bitumineux étaient dominés soit par un mélange de matière organique (MO) végétale et phytoplanctonique/bactérienne lacustre, soit par une MO lacustre biodégradée au sein de la colonne d'eau. Au cours du remplissage du bassin, on note une tendance à l'augmentation de la proportion de MO lacustre dégradée. Les résultats géochimiques et

*Corresponding author: sylvain.garel.laurin@gmail.com 
cinétiques ont montré que, excepté pour le boghead, les valeurs d'index d'hydrogène étaient $<700 \mathrm{mg} / \mathrm{g}$ COT et les énergies d'activation montraient des profils pluri-énergétiques, inhabituels pour une MO lacustre. Ajoutés à ceux des fluides primaires de pyrolysats, ces résultats ont mis en évidence deux groupes d'échantillons de schistes-bitumineux. Le premier est marqué par une dominance de la MO lacustre et terrestre bien préservée et produit des fluides primaires dominés par les $n$-alcanes avec des rapports $\left(n-\mathrm{C}_{6}-\right.$ $\left.n-\mathrm{C}_{14}\right) / n-\mathrm{C}_{14+}$ corrélés à la proportion de particules végétales. Ces échantillons proviennent des trois plus anciens niveaux de schistes bitumineux. Le deuxième groupe est marqué par une dominance de la MO lacustre dégradée, dont les profils des $\mathrm{HC}$ de fluides primaires, obtenus pour la première fois dans cette étude, montrent de faibles concentrations de $n$-alcanes et une rampe proéminente. Ce groupe ne se retrouve que dans les trois schistes bitumineux les plus récents. Enfin, le boghead montre un lien entre dominance des algues Botryococcus du genre Pila et un fluide primaire marqué par de fortes concentrations en $n-\mathrm{C}_{6}-n-\mathrm{C}_{14}$. En comparant ces données avec des études paléoenvironnementales publiées sur le bassin d'Autun, il apparaît que le type de $\mathrm{MO}$ dominante, et donc la distribution des $\mathrm{HC}$ dans les fluides primaires, est contrôlé par la hauteur d'eau dans le lac : une profondeur plus faible empêchant la mise en place de conditions anoxiques dans les eaux profondes, auxquelles est souvent associée une bonne préservation de la MO. Pendant l'Autunien, cette tranche d'eau diminue, conséquence d'une baisse de l'activité tectonique et de la mise en place d'un climat plus sec. Finalement, ces changements vont entraîner une importante diminution de la quantité de nutriments apportée dans le lac, favorisant la prolifération d'algues Botryococcus qui constituent le boghead.

Mots clés : schistes-bitumineux / environnement lacustre / kérogène de Type I / boghead / fluides primaires / géochimie organique

\section{Introduction}

For many years, lacustrine environment has been recognized as important for the preservation of oil-prone organic matter (Bohacs et al., 2000; Jarvie, 2012; Powell, 1986). These environments are especially known to allow the deposition of many rich oil-shales such as, the Green River shales in USA (Ruble et al., 2001) the Pointe-Noire Formation in Congo (Harris et al., 2004) or the Lunpola one in the Tibetan Plateau (Ma et al., 2015). Furthermore, lacustrine petroleum systems account for a significant proportion of past and current worldwide hydrocarbon production and also represent new challenges for shale oil exploration (Bohacs et al., 2000; Furmann et al., 2015; Katz, 1995; Ma et al., 2015).

The lacustrine organic matter (OM), often referred as Type I kerogen, is thought to have the highest activation energies, to be mono-energetic and to produce fluids rich in medium-heavy paraffins (i.e. $n$-alkanes with a number of carbon $>14$, also called $n$ - $\mathrm{C}_{14+}$ [Behar et al., 2010; Burwood, 1999; Derenne et al., 1994; Ruble et al., 2001; Tissot and Welte, 1984]). However, past studies of lacustrine source-rocks showed that a variation of medium-heavy paraffins concentration (i.e. $n$ - $\mathrm{C}_{14+}$ $\left./ n-\mathrm{C}_{6+}\right)$ may be encountered within a single source-rock formation (Burwood, 1999; Burwood et al., 1992; Gaglianone and Trindade, 1988; Tissot and Welte, 1984). Furthermore, as lakes contain much smaller volumes of water and sediments than oceans, their environments is much more sensitive to climate, accommodation and river discharge changes (Bohacs et al., 2000; Johnson et al., 1987; Perlmutter and Matthews, 1990). As a consequence of these variations, the lacustrine living organisms may disappear or bloom (Bohacs et al., 2000). Then, one can ask if such palaeoenvironmental variations have an effect on medium-heavy paraffins concentration of primary fluids originated from lacustrine OM.

Here we present a multi-proxy geochemical study of the lacustrine Autun Basin oil-shales, which are known as the first industrially produced oil-shales (Alpern, 1981). The sedimen- tary succession and fossil record of this basin have been studied for palaeontology, palaeoenvironmental and stratigraphy purposes since the 19th century (e.g. Heyler, 1969; Marteau, 1983; Mayer-Eymar, 1881), but no study specifically focused on the study of the fluids generated by the oil-shales beds and their relation to palaeoenvironmental settings. In this study, palynofacies will provide indications on paleoenvironments, whereas gas chromatograph analyses of primary fluids obtained by closed system pyrolysis will give the hydrocarbon profiles (i.e. chromatograms of aliphatic and aromatic compounds), which are sensitive to OM inputs and biodegradation (Peters et al., 2005). Moreover, kinetic analyses will give clues about the OM sources and the maturity. A comparison of these results will then help to determine if there is a link between palaeoenvironmental settings, OM sources and primary fluids properties for lacustrine source-rocks.

\section{The Autun Basin oil-shales}

The Autun Basin (Fig. 1) is located in Saône-et-Loire (Burgundy, France) in the north-eastern part of the Massif Central. It is an intra-cratonic lacustrine basin with a hemigraben shape linked to the Autun fault, which marks the southern boundary of the basin (Marteau, 1983) (Fig. 2). The Autun Basin is part of a series of Variscan intra-montaneous, foreland basins that can be found in the Massif Central in France (Schneider et al., 2006). It is mainly filled with lacustrine and fluvial-deltaic Permian sediments of the Autunian local stage equivalent to a late Gzhelian-Sakmarian age ( 295 Ma) (Broutin et al., 1999), which can have a maximum thickness of $1300 \mathrm{~m}$ (Marteau, 1983), and that disconformably overlies Late Carboniferous sediments of the Stephanian local stage (Fig. 3). In the Autun Basin, the base of the Autunian is defined by the coal measure of Moloy (Fig. 3), whereas the top is marked by the Curgy arkoses and conglomerates that are covered by Mesozoic sediments (Delfour et al., 1991; Marteau, 1983). 
The sedimentary succession of the Autunian is subdivided into four formations, which all show at least one oil-shale interval (Chateauneuf and Farjanel, 1989; Marteau, 1983). The lower Autunian is composed of (i) the Igornay Formation marked by the Moloy coal measure and the Igornay oil-shale bed that are surrounded by sandstones and conglomerates; and (ii) the Muse Formation that shows the Lally oil-shale bed at the base and the Muse oil-shale bed, which are intercalated with sandstones, conglomerates and clays (Fig. 3). The upper Autunian is composed of (i) the Surmoulin Formation that begins with the

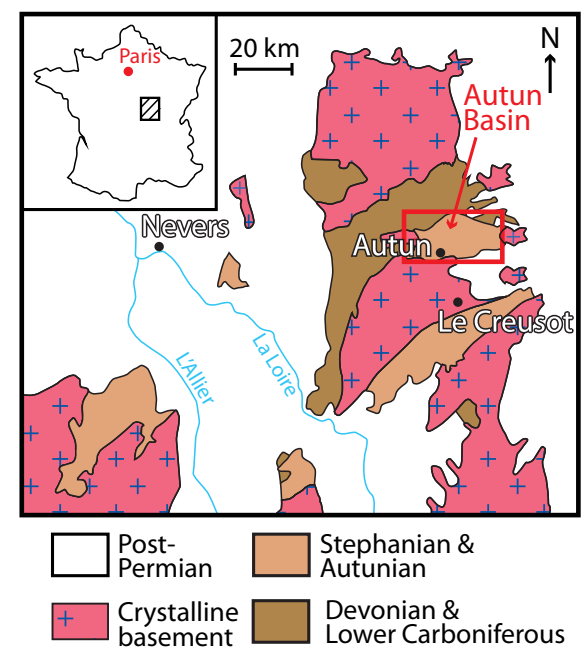

Fig. 1. Location of the Autun Basin in northeastern part of the Massif Central, France (Gand et al., 2007, modified).
Surmoulin oil-shale bed, which is overlaid by mudstones and shales with scarce intercalations of sandstones and limestones; and (ii) the Millery Formation, with, at its base a dozen of oilshale levels, "Les Télots measures", topped by the Margenne boghead bed, overlaid by calcareous mudstones and terminated by the Curgy arkoses and conglomerates (Fig. 3). The oil-shale beds have variable thicknesses throughout the basin but are at least $5 \mathrm{~m}$ thick, except for the "Les Télots" measures where each bed is approximately $2 \mathrm{~m}$ thick (Marteau, 1983). The Igornay and Lally oil-shales are thought to be early mature, whereas the other oil-shale beds are thought to be immature (Marteau, 1983). The boghead bed has a thickness of $30 \mathrm{~cm}$ and is supposed to be immature (Marteau, 1983).

Two samples of the Igornay (IG1 and IG2) and two of the Surmoulin (SU1 and SU2) oil-shales were sampled in 2009 on, respectively, the Saint-Léger-du-Bois and Surmoulin outcrops (Fig. 2). In the early 1980 's, the CA.1 and BM.1 cores (Fig. 2) were drilled by the French geological survey and stored in the Natural History Museum of Autun. The CA.1 core, from which two samples were taken (LA1 and LA2 respectively at a depth of 10 and $19 \mathrm{~m}$ ), encompasses the Lally oil-shale bed. Four samples were taken from the BM.1 core (MU1 to MU4 respectively at a depth of $16,21,25$ and $30 \mathrm{~m}$ ), which penetrated Muse oil-shale bed with a net thickness of $6 \mathrm{~m}$.

As a result of the oil-shale exploitation during the 19th and 20th centuries, most of the boghead level and the totality of the outcropping "Les Télots" measures were consumed. Thus, no samples from "Les Télots" measures were analysed. Nevertheless, one piece of the Millery boghead, which was sampled near the village of Margenne (Fig. 2), has been provided by D. Chabard, chief curator of the Natural History Museum of Autun.

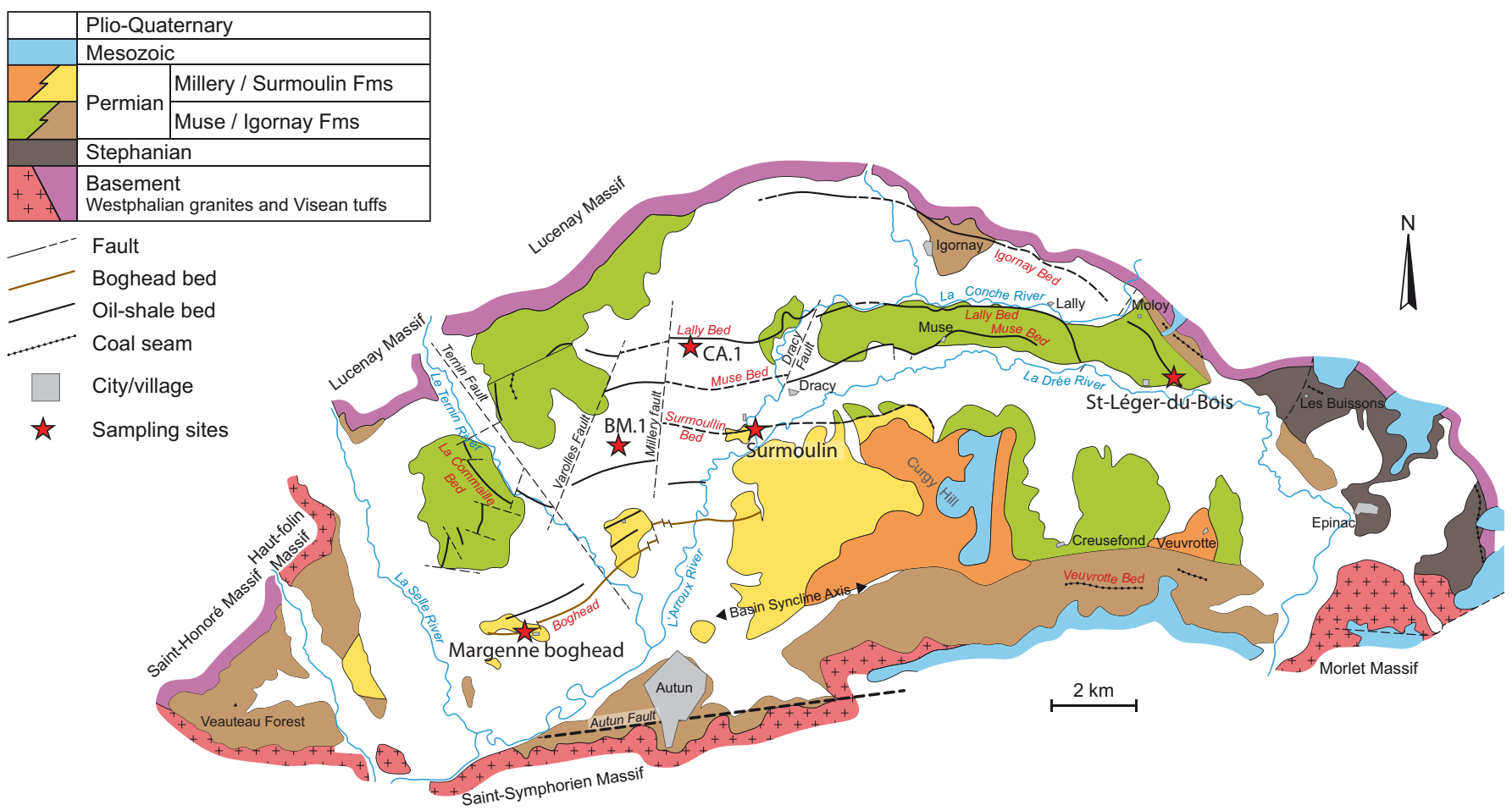

Fig. 2. Simplified geological map of the Autun Basin and location of sampling sites (Gand et al., 2007, modified). 


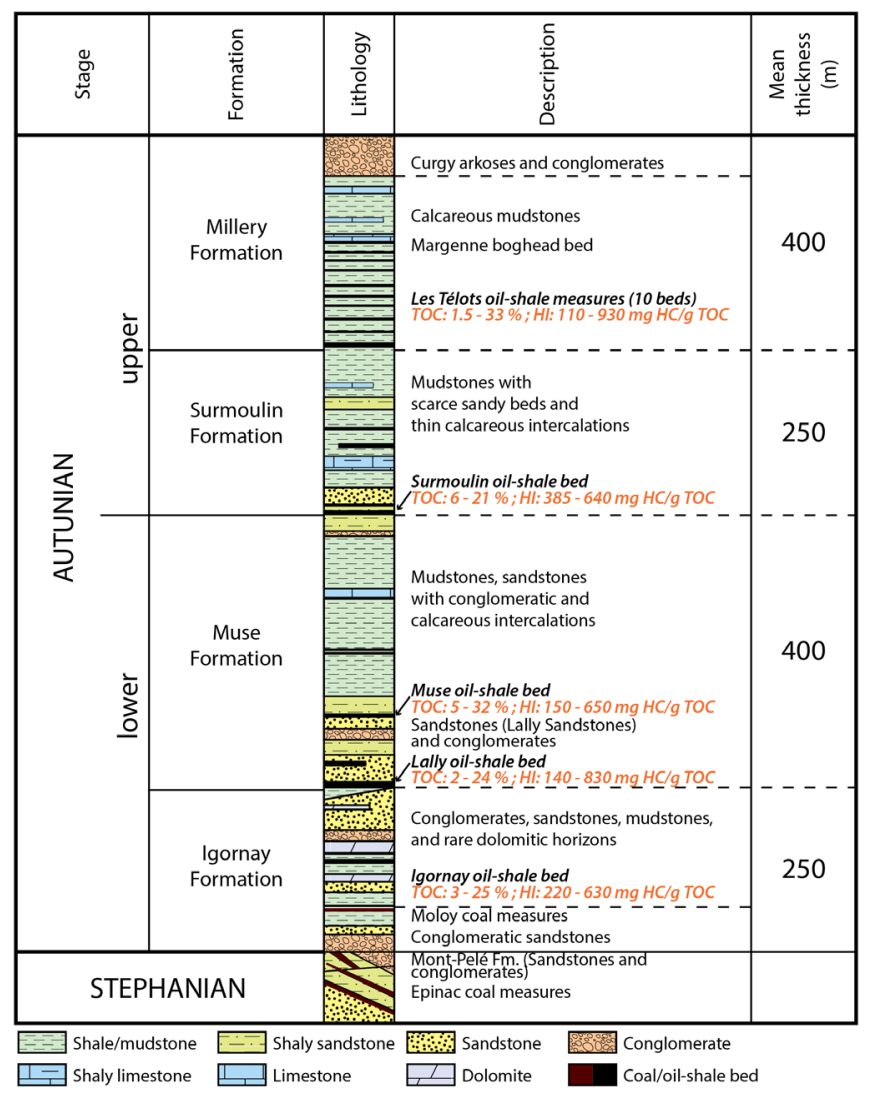

Fig. 3. Stratigraphy and lithology of the Stephanian and Autunian series of the Autun Basin (Marteau, 1983, modified).

\section{Methods}

Before analyses, the outer rim $(0.5$ to $1 \mathrm{~cm})$ of every sample was removed in order to minimize contamination. Two kerogen isolation procedures were performed using $\mathrm{HCl}$ and $\mathrm{HF}$ using the protocol described in Durand and Nicaise (1980). The first one was carried at ambient air on crushed sample for palynofacies analyses. The second one was conducted on powdered samples under a nitrogen atmosphere to prevent any organic matter oxidation and their soluble OM was removed with dichloromethane. These kerogens were then used for Rock-Eval 6 analyses and artificial maturation in closed pyrolysis system.

\subsection{Palynofacies analyses}

Palynofacies observations were carried out on all samples with an Axioplan2 Imaging Zeiss microscope under transmitted light and under UV excitation (Zeiss HBO 100 Microscope Illuminating System, mercury short-arc lamp) with a magnification of 630. About 2000 surface units were counted per sample on non-filtered slides to estimate the relative $\%$ of each organic group.

\subsection{Rock-Eval 6 analyses}

Depending on the OM content, between 2 and $50 \mathrm{mg}$ of dried and powdered bulk rocks and kerogens were used for
Rock-Eval 6 analyses to obtain: (i) Total Organic Content (TOC, \%), which accounts for the quantity of OM present in the sediment; (ii) Hydrogen Index (HI, mg/g TOC), which is the amount of hydrocarbonaceous products released during pyrolysis normalized to TOC; (iii) Oxygen Index (OI, $\mathrm{mg} \mathrm{CO}_{2} /$ $\mathrm{g}$ TOC), calculated from the amounts of $\mathrm{CO}$ and $\mathrm{CO}_{2}$ released during pyrolysis, which is the labile oxygen content of the $\mathrm{OM}$; and (iv) Tmax $\left({ }^{\circ} \mathrm{C}\right)$, which is the temperature of the pyrolysis oven recorded at the maximum of $\mathrm{HC}$ production. Tmax is a good indicator of OM maturity in ancient sediments (Espitalié et al., 1985). However, this parameter cannot be used to assess the maturity of Type I OM (often linked to lacustrine settings) as they display a narrower distribution of Activation energies (Ea) that also display higher values (Behar et al., 2010). Indeed, when the Ea distribution is broad like in Type III, this means that there is a large spectrum of chemical bonds that will break at different temperatures. Therefore, this kind of OM will show a significant Tmax increase during thermal maturation, which is not the case of Type I OM.

\subsection{Closed system pyrolysis and primary fluid analysis}

Gold tubes reactors $(6 \mathrm{~cm} \times 1.6 \mathrm{~cm})$ were used to perform closed pyrolysis on 220 to $350 \mathrm{mg}$ of kerogen. The filling and sealing of the tubes were carried out inside a glove box under nitrogen atmosphere. The sealed gold reactors were then placed into an autoclave for heating at $325^{\circ} \mathrm{C}$ during $24 \mathrm{~h}$. At the end of the pyrolysis time, the autoclave was slowly depressurized and cooled in a water-bath.

For recovering the saturated and aromatic hydrocarbons, the gold tube was pierced, cut into pieces and placed in a flask filled with $n$-pentane. The flask was then constantly stirred for $1 \mathrm{~h}$ at reflux. After filtration, the $n$-pentane solution was concentrated to $8 \mathrm{ml}$. An aliquot of $1 \mathrm{ml}$ was injected into a GC coupled with a flame ionization detector (FID) to obtain the hydrocarbon profiles. A deuterated $n$ - $\mathrm{C}_{24}$ was added as internal standard for quantification of the $\mathrm{C}_{6}+n$-alkanes.

GC-FID analyses were performed on an Agilent 6890 gas chromatograph. The GC was fitted with a Varian capillary column ce-sil $5 \mathrm{CB}(100 \mathrm{~m} \times 0.53 \mathrm{~mm}$ i.d., $0.5 \mu \mathrm{m}$ film thickness) with $1.5 \mathrm{~m}$ of guard column. The sample was dissolved in $n$-pentane and injected in a $1 \mu \mathrm{l}$ volume. Helium was the carrier gas.

\subsection{Bulk kinetics}

Five kerogens, one per oil-shale bed plus one from the boghead, were selected for bulk kinetics analyses using a Rock-Eval 6 according to the method described in Behar et al. (2008). Briefly, to acquire bulk pyrolysis data (i.e. Ea and frequency factor, $A$ ) isolated kerogens were pyrolysed using multiple heating rates: $2,5,10,15$ and $25^{\circ} \mathrm{C} / \mathrm{min}$, starting from an isotherm at $200^{\circ} \mathrm{C}$ during $15 \mathrm{~min}$, then increasing the temperature to $700^{\circ} \mathrm{C}$. The resulting data files were then utilized to compute bulk kinetic parameters using the Geokin software, a kinetic simulator developed by the French Petroleum and Renewable Energies Institute. Twenty-one kinetic distributions coefficients were calculated for every even-value of $E a$ between 40 and $80 \mathrm{kcal} / \mathrm{mol}$, each one 
Table 1. Rock-Eval 6 and palynofacies results, and hydrocarbon concentration of pyrolysate of the Autun samples. TOC: Total Organic Carbon; HI: Hydrogen Index; OI Oxygen Index; nGP: non-gelified phytoclasts; fAOM: fluorescent Amorphous Organic Matter; dAOM: diffuse Amorphous Organic Matter; gOM: gelified Organic Matter. $*$ Biodegraded samples with low concentrations of $n$-alkanes.

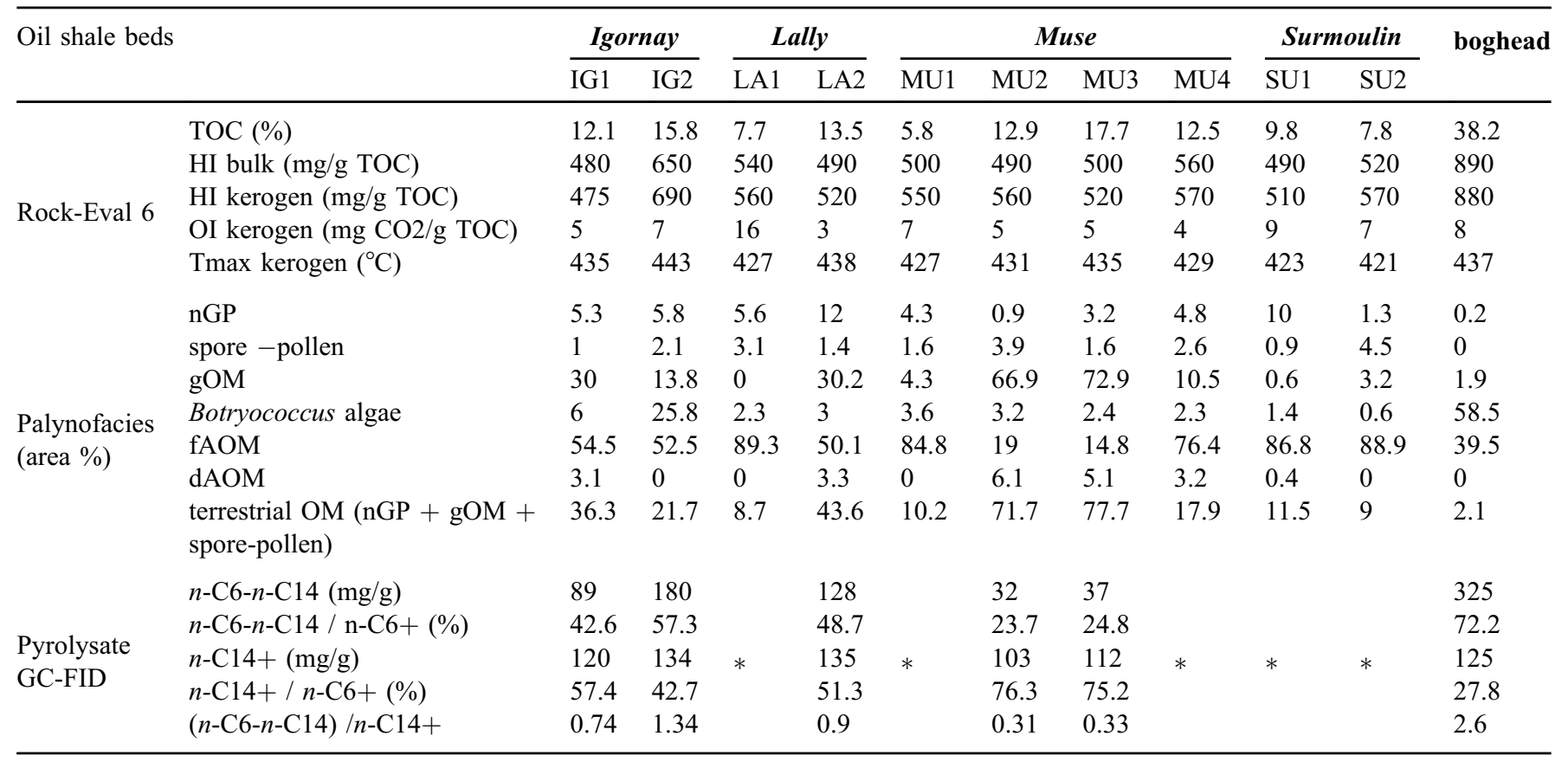

accounting for the contribution of each reaction to the bulk rate of petroleum formation.

\section{Results}

\subsection{Rock-Eval 6}

TOC content ranged between 5.8 and $17.7 \%$ in the oil-shale samples and reached $38.2 \%$ in the boghead (Tab. 1). The HI bulk values ranged from 480 to $890 \mathrm{mg} / \mathrm{g}$ TOC (Tab. 1). HI values of kerogens are comparable to bulk rocks ones (Tab. 1). In order to compare our results with other studies, we will only discuss the HI values of kerogens (Tab. 1). These values range from 475 to a maximum of $880 \mathrm{mg} / \mathrm{g}$ TOC in the boghead, with most of the oilshale values below $580 \mathrm{mg} / \mathrm{g}$ TOC, which is relatively low for Type I organic matter (Espitalié et al., 1985). In kerogens, the OI values were all below $16 \mathrm{mg} \mathrm{O}_{2} / \mathrm{g}$ TOC and Tmax ranged between 421 and $443{ }^{\circ} \mathrm{C}$ with a clear correlation with the age of the oil-shale level, the oldest (i.e. Igornay) displaying the highest values (Tab. 1). However, the Tmax values can vary by more than $10^{\circ} \mathrm{C}$ within a single oil-shale bed as in the Muse one (Tab. 1), a variation that cannot be explain by maturity differences as the samples have similar depth.

\subsection{Palynofacies}

Three main groups of particles were observed (Fig. 4): (i) the phytoclast group, subdivided into gelified phytoclasts and non-gelified phytoclasts (Fig. 4B); (ii) the palynomorph group, comprising freshwater algae Botryococcus as well as spores and pollen grains (Fig. 4E and F); (iii) the Amorphous Organic Matter (AOM) group, subdivided into gelified AOM (Fig. 4B), fluorescent AOM (fAOM; Fig. 4A) and diffuse nonfluorescent AOM (dAOM; Fig. 4C). As gelified AOM and gelified phytoclasts correspond to plant tissues that suffered gelification (Batten, 1996), they will both be further referred to as gelified OM (gOM).

The main palynofacies results are shown in Table 1 . The oil-shale samples are dominated by fAOM with relative concentrations $>50 \%$ except for MU2 and MU3 samples that displayed a $\mathrm{gOM}$ relative concentration $>65 \%$. Concerning the fAOM, the fluorescence intensity was weaker in samples LA1, MU1, MU4, SU1 and SU4 than in other samples. The concentration of terrestrial $\mathrm{OM}$ was obtained by summing nGP, spore-pollen and gOM. Its values varied between 2.1 and $78 \%$ (Tab. 1), with four samples having concentrations $>35 \%$, indicating strong inputs of terrestrial materials in the lake environment (Batten, 1996; Tyson, 1995). Samples IG2, LA2 and SU1 displayed significant differences in the organic content with, strong concentration in Botryococcus algae $(26 \%)$ in the former, and in nGP $(>10 \%)$ in the 2 others. The boghead is dominated by Botryococcus algae $(58.5 \%)$ and fAOM $(39.5 \%)$ with almost no terrestrial particles. Finally, diffuse AOM was found in minor concentrations $(<7 \%)$ in Igornay, Lally and Muse samples, generally associated with relatively high terrestrial OM concentrations $(>17 \%)$.

\subsection{Hydrocarbon composition of pyrolysates}

Hydrocarbon distributions of Autun pyrolysates showed 4 kinds of profiles (Fig. 5): (i) one with a dominance of $n-\mathrm{C}_{6}$ to $n-\mathrm{C}_{14}$ and low relative concentrations of $n-\mathrm{C}_{14+}(28 \%$ of total $n$-alkanes concentrations; Tab. 1), which characterize the boghead; (ii) a second with a dominance of $n-\mathrm{C}_{6}$ to $n-\mathrm{C}_{14}$ but 

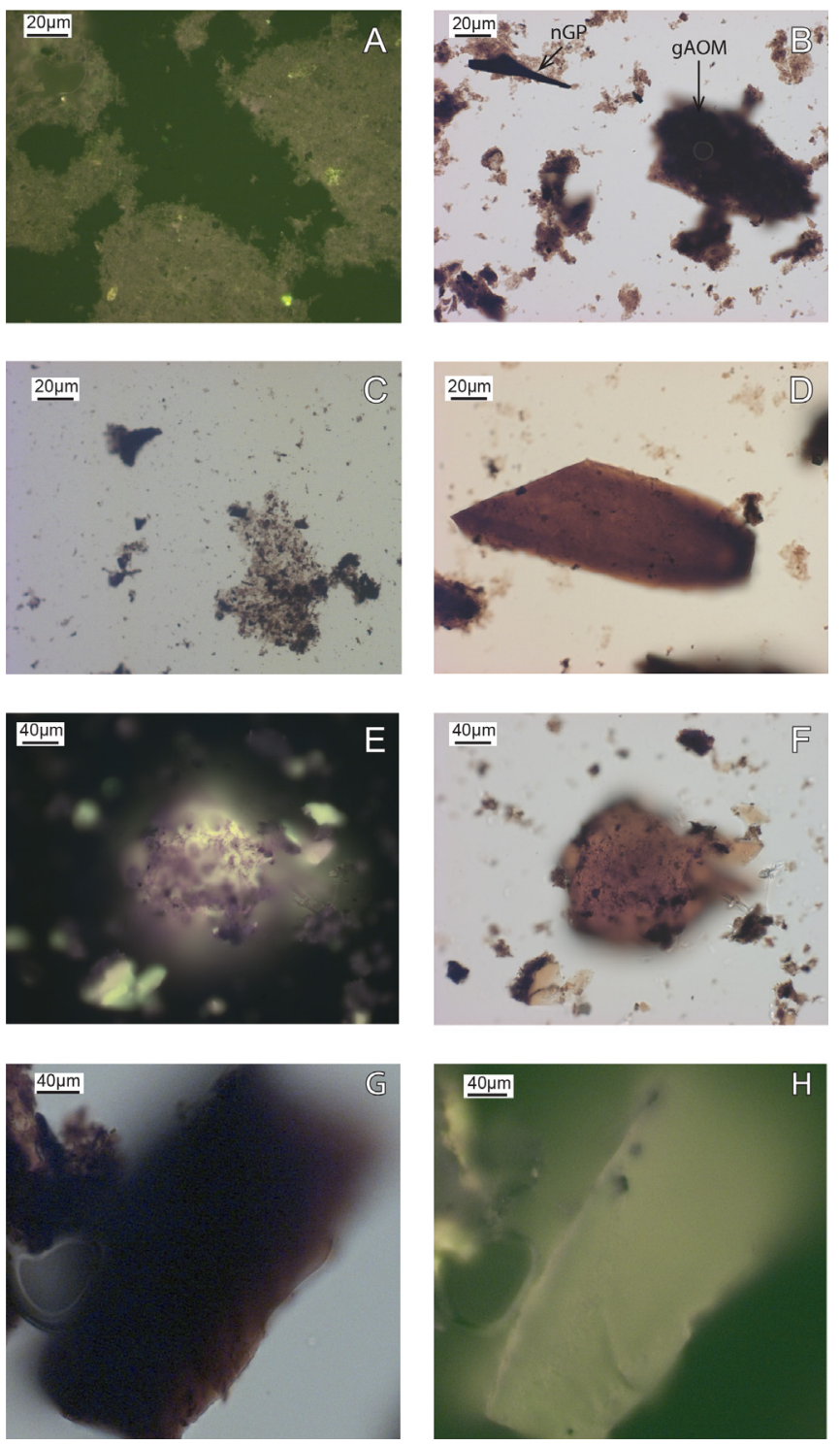

Fig. 4. Palynofacies main categories: (A) fluorescent amorphous organic matter under UV; (B) non-gelified phytoclast (nGP) and gelified amorphous organic matter (gAOM); (C) degraded amorphous organic matter; (D) gelified phytoclast; Botryococcus algae under UV (E) and transmitted light (F); and a gelified cuticle in transmitted light (G) and under UV (H).

with significant concentrations of $n-\mathrm{C}_{14+}(43 \%)$ only seen in IG2 (iii) a third dominated by $n-\mathrm{C}_{14+}$ and showing various relative concentrations of $n-\mathrm{C}_{6}$ to $n-\mathrm{C}_{14}$ (from 25 to $49 \%$ of total $n$-alkanes) in IG1, LA1, MU2 and MU3; and (iv) a last one characterized by low $n$-alkanes concentrations compared with other compounds such as iso-alkanes and cycloalkanes and displaying a chromatographic baseline hump (i.e. unresolved complex mixture; UCM) seen in SU samples, LA1, MU1 and MU4. Such characteristic is generally explained by a slight to moderate biodegradation of the OM (Wenger and Isaksen, 2002; Peters et al., 2005). Similar profiles are also seen in pyrolysates of Botryococcus algae
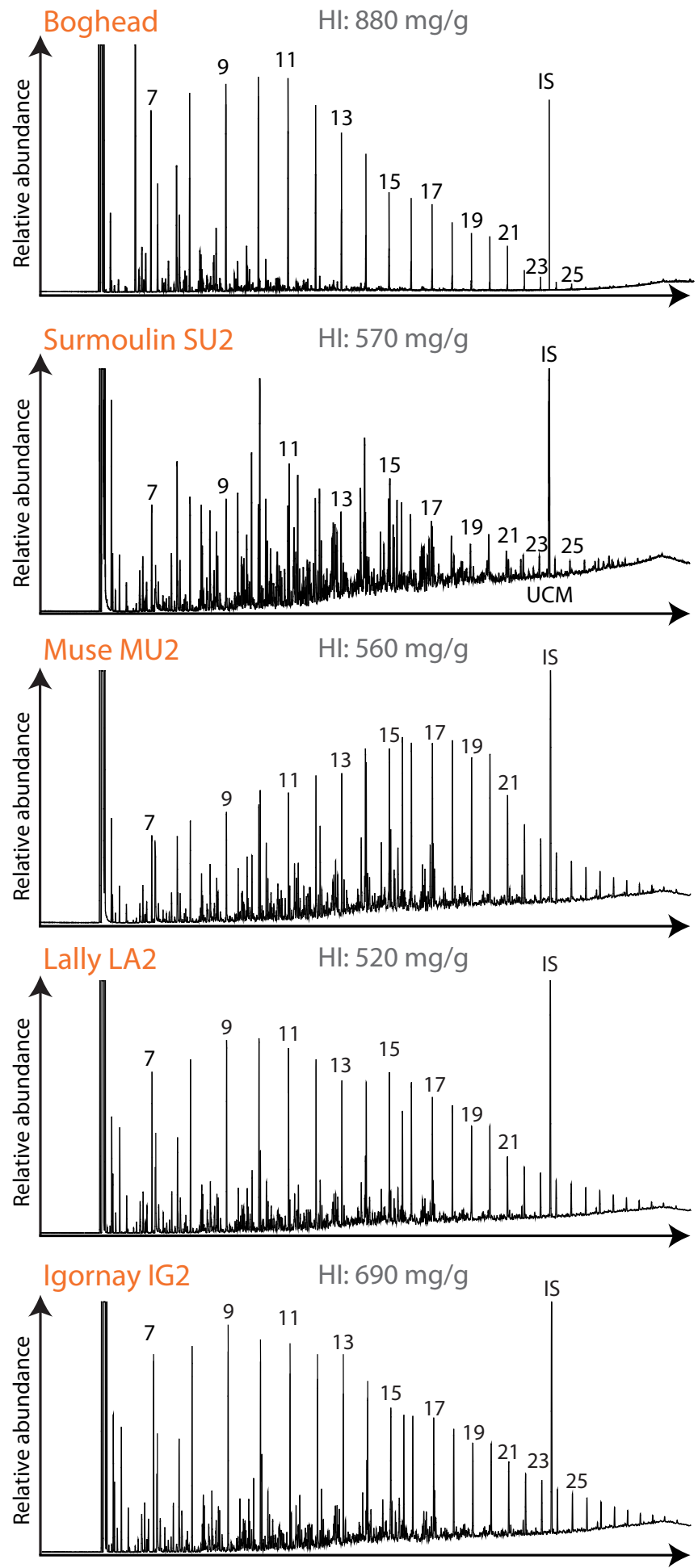

Retention time

Fig. 5. GC-FID of hydrocarbons obtained during closed system pyrolysis of the boghead, Surmoulin SU2, Muse MU2, Lally LA2, and Igornay IG2 samples, representative of the groups defined in the results section. Numbers above peaks represent carbon number of the respective $n$-alkane. IS = internal standard; UCM: unresolved complex mixture. 

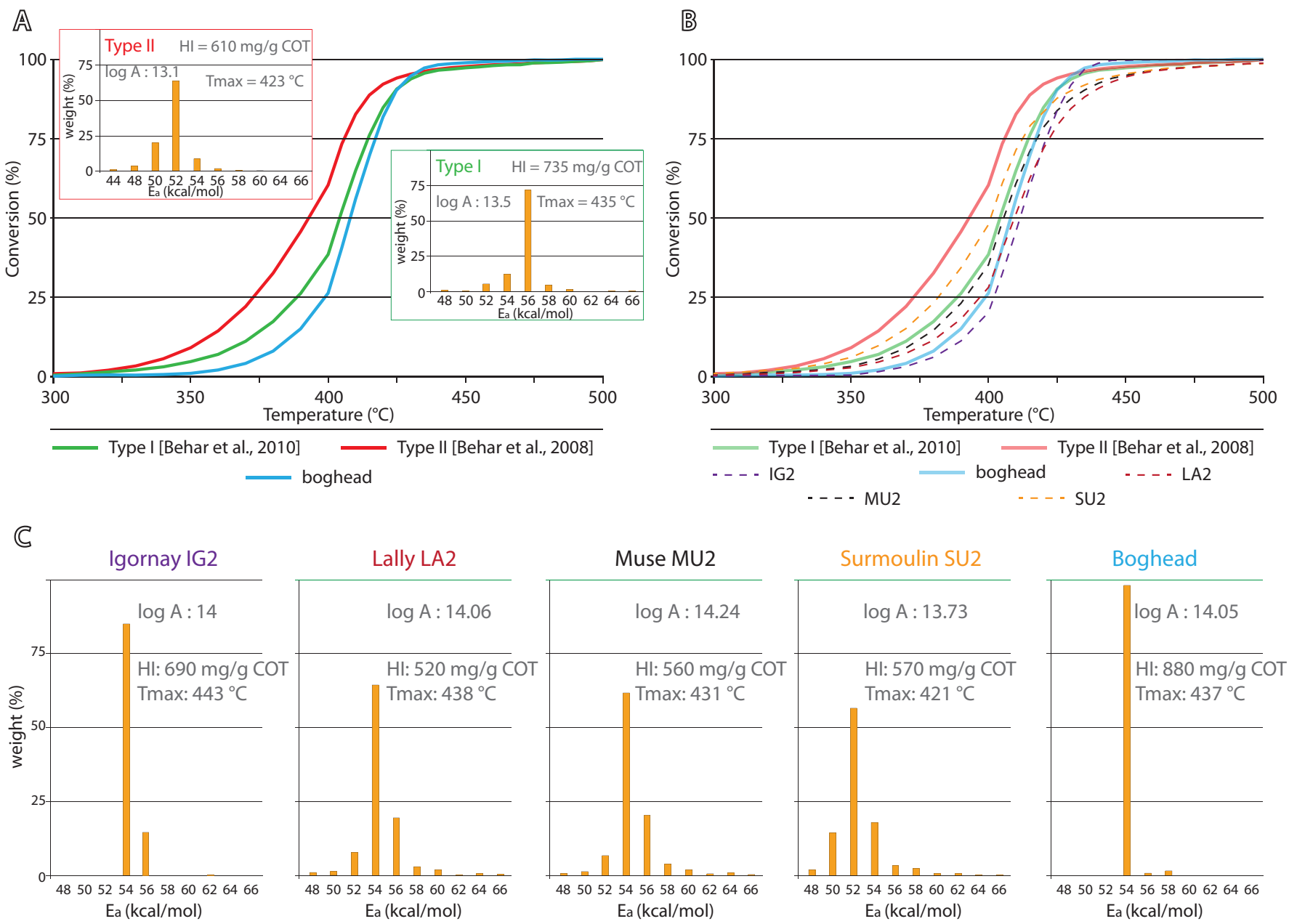

Fig. 6. Conversion curves of kerogens with increasing temperature of: the boghead (this study) and typical Type I from the Green River Shales (Behar et al., 2010) and Type II from the Toarcian of the Paris Basin (Behar et al., 2008) kerogens (A); and Autun oil-shales (B). C: kinetic parameters diagrams of the Autun samples (this study).

races producing outer walls of the PRB L type (Derenne et al., 1994). However, such pyrolysates show lower $n$-alkanes concentrations compared to the Autun samples and no UCM. Furthermore, palynofacies results of the 4th group samples show only minor concentrations of Botryococcus algae (Tab. 1), thus excluding a PRB L origin of this specific HC distribution.

A $\left(n-\mathrm{C}_{6}-n-\mathrm{C}_{14}\right) / n-\mathrm{C}_{14+}$ ratio was calculated to determine the relative abundance of light paraffins in the pyrolysates, except for the last category of HC distribution, for which it was not relevant. Values ranged between 0.31 , for MU2 and 2.6 for the boghead, being $<1$ in samples of the 3rd group (Tab. 1).

\subsection{Bulk kinetics}

Main kinetic results are displayed in Figure 6. When compared to a typical Type I from the Green River Shales (GRS) composed of bacterial remains with similar Tmax values (Behar et al., 2010), the Autun boghead appeared more mono-energetic and refractory (i.e. resistant to thermal cracking) with an $E a$ of $54 \mathrm{kcal} / \mathrm{mol}$ but its kerogen conversion curve displayed a similar evolution. The Igornay sample IG2 was the only oil-shale sample that showed a pattern with one $E a$ representing more than 80 weight \% like the boghead one, while the others displayed a pluri-energetic pattern with the dominant $E a$ ranging between 50 and $60 \mathrm{kcal} / \mathrm{mol}$.

The kerogen conversion curves of the Autun samples showed that all the samples except SU2 are more refractory than the GRS Type I. Three curve patterns were observed: (i) one boghead-like pattern displayed by Igornay IG2; (ii) one intermediary pattern between the boghead and the GRS corresponding to Lally LA2 and Muse MU2 samples, the latter being less refractory; and (iii) an intermediary pattern between Type I and Type II displayed by Surmoulin SU2 sample.

\section{Organic matter sources and maturity of oil-shales}

Whatever the considered oil-shale bed, all kerogens from the Permian Autun Basin show HI values systematically below $700 \mathrm{mg} / \mathrm{g}$ TOC, unexpectedly low for a Type I OM (Espitalié et al., 1985) and do not display mono-energetic Ea distribution, which characterize pure lacustrine OM (Behar et al., 2010; Lewan and Ruble, 2002; Tegelaar and Noble, 1994; Ungerer 
and Pelet, 1987) like in the boghead sample. These characteristics could be explained by maturity and/or by mixing of different OM types.

In Igornay, the IG2 sample shows a dominance of fAOM and Botryococcus algae, indicative of a phytoplanktonic/ bacterial origin of OM (Batten, 1996) and a terrestrial OM content (i.e. $\mathrm{nGP}+\mathrm{gOM}+$ spore-pollen) of $21 \%$. The presence of these 2 kinds of OM may explain the bi-energetic activation energy diagram (Fig. 6) and the relatively low HI values for a lacustrine $\mathrm{OM}$ as terrestrial $\mathrm{OM}$ has relatively lower HI than algal OM (Espitalié et al., 1985). However, the palynofacies also show that this terrestrial OM has a dark brown colour (Fig. 4B), which can be indicative of a low maturity ( Batten, 1996; Staplin, 1977). This is supported by the kerogen conversion trend of this sample, slower than the boghead despite having similar OM assemblages (Tab. 1). It also concords with the conclusions of Marteau (1983) on the early maturity of the Igornay oil-shale bed. In the IG1 sample, the lower HI values (475 mg/g TOC) can be explained by the higher relative concentration of terrestrial OM (Tab. 1). Thus, in Igornay, the relatively low HI values are explained by maturity (both samples), and mixed OM sources: phytoplanktonic/bacterial and terrestrial (especially in IG1).

If we consider Lally LA2 and Muse MU2 samples, they display similar kinetic parameters: multi-energetic activation energy profiles and kerogen conversion curves (Fig. 6). However, the Lally sample is more refractory than the Muse one, which, along with the higher Tmax values suggest that this sample OM is more mature. This assumption is confirmed by the study of Marteau (1983). Furthermore, these samples and MU3 all display terrestrial OM content $>40 \%$ that can explain the relatively low HI values. However, one can ask why these values are not closer to a typical Type III OM (i.e. 150-300 mg/g TOC [Espitalié et al., 1985]). This may be due to the fact that the terrestrial particles of these 3 samples are mostly non-gelified and gelified cuticles (Fig. $4 \mathrm{G}$ and $\mathrm{H}$ ), which are known to have an HI, when immature, close to Type II OM $\approx 650 \mathrm{mg} / \mathrm{g}$ TOC (Tyson, 1995), much higher than the ligneous material of Type III OM. Thus for these samples, the relatively low $\mathrm{HI}$ values are explained by strong concentrations in terrestrial OM (all samples) and maturity (Lally LA2).

Finally, 4th group, samples (i.e. LA1, MU1, MU4, SU1 and SU2) all display palynofacies dominated by fAOM (Tab. 1). Yet, they display HI values ranging from 510 to $570 \mathrm{mg} / \mathrm{g}$ TOC despite that fAOM, originating from phytoplankton/bacteria (Batten, 1996), is thought to have HI values $>750 \mathrm{mg} / \mathrm{g}$ TOC (Tyson, 1995). If maturity can explained the relatively low HI values for Lally LA1, it is not the case of the other oil-shale samples as they are thought to be immature (Marteau, 1983). This is confirmed by the kerogen conversion curve of the sample SU2 that is less resistant to thermal cracking than a typical immature Type I kerogen (Fig. 6), and by Tmax values below $430^{\circ} \mathrm{C}$ for all samples (Espitalié et al., 1985). These relatively low HI values may be explained by biodegradation of the OM in the water column, or even in the first $\mathrm{cm}$ of the sediments. The TOC values $>7.5 \%$ in these samples would then be explained by high primary productivity and a low OM dilution due to relatively low detrital inputs in the lake. Assumption of possible biodegradation is consistent with their HC profiles that all show a prominent hump and low $n$-alkanes concentrations (Fig. 5) (Peters et al., 2005; Wenger and Isaksen, 2002). It is also supported by the weaker intensity of fAOM fluorescence in these samples compared to the other (Tyson, 1995). Finally, this hypothesis is supported by a former study on trace elements, which showed $\mathrm{V} / \mathrm{Cr}$ ratios around 2.5 and $\mathrm{Ni} / \mathrm{Co}$ ratios around 3.5 in Surmoulin samples (Chateauneuf et al., 1982). These values indicate dysoxic conditions in bottom waters (Tribovillard et al., 2006), and stronger $\mathrm{Ni} / \mathrm{Al}$ and $\mathrm{Cu} / \mathrm{Al}$ compared to Igornay samples, suggestive of higher primary production during the Surmoulin deposition (Tribovillard et al., 2006).

\section{Depositional environment evolution}

Marteau (1983) explained the formation of oil-shale deposit by a temporary settlement of a swamp on lake shores, which would trap most of the terrigenous inputs to the lake. However, this study does not discuss about the differences in environmental conditions during oil-shale deposition. Our results allow to go further in the interpretation of palaeoenvironmental conditions during deposition of these beds.

The Autun oil-shale display variable relative concentrations in terrestrial OM (9-78\%; Tab. 1), with values $>20 \%$ only found in Igornay, Lally and Muse beds. All Surmoulin samples, from both present study (Tab. 1) and previous work (Lebedel, 2009) display low concentrations in terrestrial OM. Samples with significant proportions of terrestrial OM are also characterized by dAOM relative concentrations $>3 \%$. This type of organic particle traces, when associated with strong terrestrial OM concentration, a source from soil layers (Sebag et al., 2006), thus indicative of detrital inputs in the environment (Tyson, 1995). On the other hand, degraded fAOM was only observed in Lally, Muse and Surmoulin beds. Therefore it seems that there is an upward trend of increasing concentration of biodegraded lacustrine OM in the Autun oilshales. This trend could be related to variations in redox conditions of the water column, and a decreasing trend of terrestrial OM contribution that could be linked to a diminution though time of the detrital flux.

The Autun Permian lake was located near the equator in the middle of the Variscan mountains (Schneider et al., 2006) and is thought to have been relatively shallow, with its depth decreasing during the Autunian (Marteau, 1983). If this low depth did not prevented anoxic bottom waters during Igornay deposition (Marteau, 1983), in Lally and Muse oil-shales, the absence of benthic fauna and the occurrence of phytoplankton and fishes fossils suggest that the anoxic part of the water column was very close to the bottom of the lake (Gall, 1979; Marteau, 1983). A decrease of the lake level could thus have caused the disappearance of anoxic conditions in the bottom waters such as in the Lake Bosumtwi (Ghana) during the Younger Dryas (Shanahan et al., 2006). Therefore, the increasing trend of biodegraded lacustrine OM concentration can be explained by the shallowing of the lake, which would have, in fine, prevented the presence of perennial anoxic bottom waters.

The HI values $\approx 700 \mathrm{mg} / \mathrm{g}$ TOC and a dominance of fAOM found in Igornay IG1 suggest that the OM did not suffer from severe biodegradation (Tyson, 1995), confirming Marteau, (1983) assumption that the water column was partly anoxic. The significant proportions of terrestrial OM seen in Igornay 
samples, indicating relatively high detrital inputs, can be linked to the strong tectonic activity and the moister climate of the lower part of the Autunian (Broutin et al., 1990; Galtier, 1980; Marteau, 1983), which could have increased the weathering in the catchment area of the Autun Permian lake, thus increasing the terrestrial inputs.

Concerning the Lally and Muse oil-shale beds, they are thought to have been deposited during an interval marked by a transitional climate with alternation of wet and dry periods (Marteau, 1983; Parrish, 1993; Ziegler, 1990). In these samples, the palynofacies are either dominated by degraded fAOM (i.e. LA1, MU1, MU4) or characterized by high terrestrial OM concentrations (i.e. LA2, MU2, MU3; Tab. 1), thus reinforcing their transitional imprint between Igornay and Surmoulin oil-shales. These variations of palynofacies assemblages within a single bed, may be explained by a variation of climatic conditions. Indeed, samples dominated by biodegraded lacustrine OM would have been deposited during a dryer period, thus decreasing the lake level and preventing the presence of anoxic bottom waters. The other samples would then be linked to wetter conditions, allowing anoxic conditions in the hypolimnion, and causing an increase of detrital influx, and thus of terrestrial OM inputs in the environment.

It is also known that the tectonic activity was very low since the Surmoulin Formation deposition (Marteau, 1983), causing a diminution of the accommodation space in the basin. Furthermore, micro- and macro-flora studies suggest that the climate was dryer during the upper Autunian (Galtier, 1980; Marteau, 1983). These climatic and tectonic changes are thought to be responsible of the decrease of the lake depth and area since the Surmoulin bed deposition (Marteau, 1983), a depth that would not be sufficient to allow the presence of anoxic bottom waters. This would have permitted the biodegradation of the lacustrine OM within the water column. Moreover, the dryer climate and lower tectonic activity could explain the relatively low concentration of higher plant OM observed in the Surmoulin oil-shale, as it caused a decrease in terrestrial inputs. A decrease that also supports the hypothesis of a lower OM-dilution during the deposition of this bed as discussed above.

Finally, the dominance of Botryococcus algae in the boghead level indicates that the competitiveness between species was low during its deposition (Tyson, 1995). This can be a result of a higher salinity or of a lack of nutrient in the environment (Tyson, 1995). The nearly absence of phytoclasts and gOM in the boghead (Tab. 1) indicate that the terrestrial organic inputs to the lake were very low during its deposition, and thus support the hypothesis of an oligotrophic environment. Low nutrients content in the environment is often linked to low detrital influx, which may be related in Autun to the end of both tectonic activity and high subsidence rate in the basin that occurs during the deposition of the Millery Formation (Marteau, 1983).

Thus, it seems that the differences between the Autun oilshale OM compositions are directly related to the variation of the lake depth, which is linked to the evolution of the climatic conditions and of the tectonic activity. The diminution of this activity and the settlement of a dryer climate went along with a decrease in terrestrial OM and nutrient inputs that caused, in fine, the settlement of oligotrophic conditions.

\section{Relation between primary fluids hydrocarbon distribution and palaeoenvironmental settings}

In Autun, 4th group pyrolysates (i.e. LA1, MU1, MU4, SU1 SU2) show a relatively prominent hump but are still dominated by light hydrocarbons including iso- and cycloalkanes (Fig. 5), which is generally associated with slight to moderate biodegradation (Meyers and Eadie, 1993; Peters et al., 2005; Wenger and Isaksen, 2002). Indeed, past studies on the fate of OM particles in oxygenated lake water column and sediments showed a degradation of algal lipids with a preference for $n$-alkanes and some of their precursors like $n$ alkanoic acids (Kawamura et al., 1987; Meyers and Eadie, 1993; Meyers and Ishiwatari, 1993). In aerobic environment, biodegradation of resistant compounds such as hydrocarbons is possible through incorporation of oxygen to form alcohols and carboxylic acids to be consumed as food or converted as biolipids by bacteria (Fritsche and Hofrichter, 2000; Peters et al., 2005). Concerning the Autun samples, as discussed above, it is likely that these samples were deposited in an environment with strong primary productivity but with dysoxic to oxic conditions, allowing a significant aerobic biodegradation within the water column and/or sediments causing a decrease in $n$-alkanes concentrations. Thus, for the first time, our study shows that the typical HC distribution of pyrolysates originating from biodegraded lacustrine $\mathrm{OM}$ is marked by very low concentrations of $n$-alkanes $\mathrm{C}_{6}-\mathrm{C}_{14}$ and consequently a dominance of other light hydrocarbons and a prominent hump.

The 5 other oil-shale pyrolysates (i.e. IG1, IG2, LA2, MU2, MU3) show an HC distribution marked by significant concentrations or the dominance of $n-\mathrm{C}_{14+}$ compounds (Fig. 5; Tab. 1). The heavy paraffins in oils are generally linked to the presence of either bacterial or terrestrial waxes in the kerogen (Tissot and Welte, 1984). In Autun, the samples display variable proportions of terrestrial OM (22 to 78\%; Tab. 1) and $\left(n-\mathrm{C}_{6}-n-\mathrm{C}_{14}\right) / n-\mathrm{C}_{14+}$ ratio ranging from 0.31 to 1.34. Moreover, these parameters seem correlated as the strongest relative concentration of terrestrial OM displays the lowest $n$-alkane ratios and vice versa. This suggests that the medium-heavy paraffins concentrations in the Autun pyrolysates are directly linked to terrestrial contribution to the OM assemblage.

Thus, this study confirms that different HC distributions can be encountered within a single lacustrine formation, and even within a single oil-shale bed. On one hand, in the Autun Basin, primary fluids with low $n$-alkanes concentrations and prominent hump are linked to a lacustrine OM biodegraded within the water column and/or the sediments, which was an indirect consequence of particular climatic and tectonic conditions. On the other hand, the presence of medium- and heavy-paraffins in the pyrolysates are directly linked to the concentration of terrestrial $\mathrm{OM}$ in the kerogen, and probably to depositional environment conditions allowing optimal OM preservation. However, this may not explain the dominance of $\mathrm{C}_{14+}$ compounds in other lacustrine formations, such as the GRS one and the Bucomazi Formation (Angola) where there is a lack of terrestrial OM (Burwood, 1999; Ruble et al., 2001). 


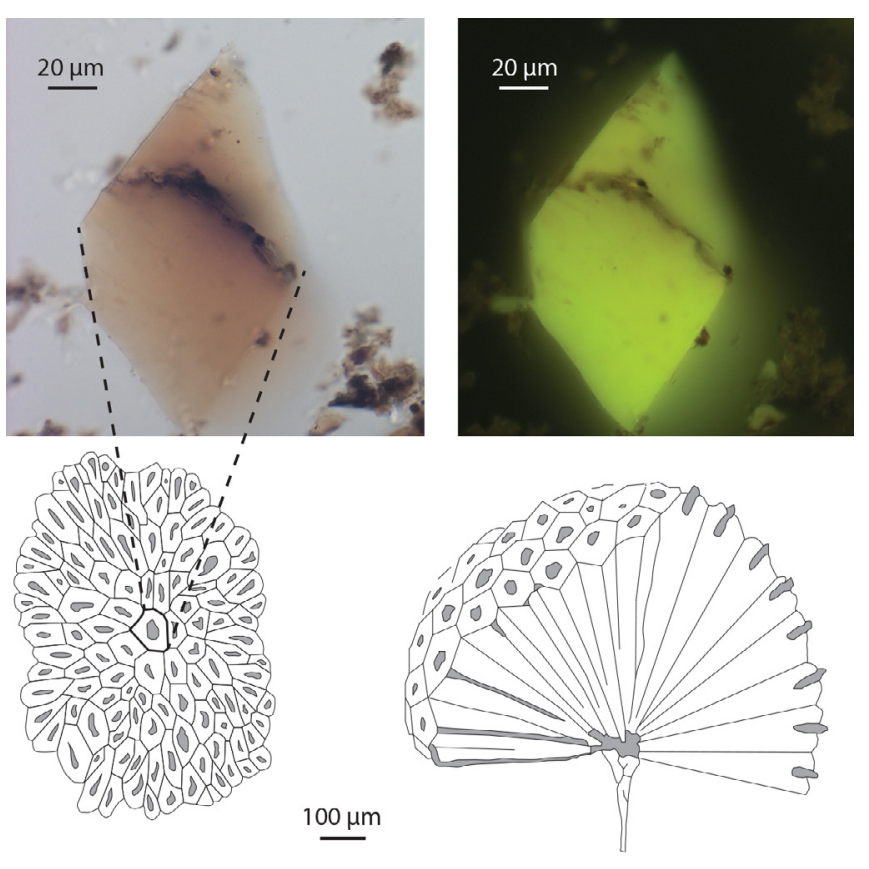

Fig. 7. Views of a Botryococcus Pila colony from above and in a vertical-radial section (after Bertrand and Renault, 1892; Bertrand, 1930 in Alpern, 1981) and one cell of a colony seen in transmitted light and under UV.

\section{The particular case of the Autun boghead}

The hydrocarbon distribution of the boghead primary fluids (Fig. 5) only shows very low amount of $\mathrm{C}_{14+}$ compounds when compared to other torbanites (i.e. Botryococcus-rich oil-shales), which generally show a dominance of $\mathrm{C}_{14+}$ compounds (Derenne et al., 1994). A previous study suggested that the particular HC distribution of Autun pyrolysate was a result of its higher maturity compared to other torbanites (Derenne et al., 1994; Largeau et al., 1986). However, the strong yellow fluorescence (Fig. 4) of the Botryococcus as seen in palynofacies and the HI of almost $900 \mathrm{mg} / \mathrm{g}$ TOC does not support this hypothesis (Espitalié et al., 1985; Teichmüller and Durand, 1983; Teichmüller and Wolf, 1977). Nevertheless, the Autun boghead is known since the 19th century for being composed of a particular genus of Botryococcaceae: Pila bibractensis, known for their cells that are radially disposed and pyramidal in shape (Bertrand and Renault, 1892). Their internal cells also have the particularity to be polygonal in outline (Fig. 7), which is not the case of Botryococcus braunii that compose most of the world torbanites (Alpern, 1981; Tyson, 1995). As this boghead has been deposited in an oligotrophic lacustrine environment and as Pila bibractensis have not been observed in the Autun oilshale beds (i.e. the Botryococcus seen in these beds are like Fig. $4 \mathrm{E}$ and $\mathrm{F}$ ), it is likely that this particular genus of Botryococcaceae was adapted to such conditions. Moreover, the difference in $\mathrm{HC}$ distribution of the Autun boghead primary fluid compared to other torbanite may be due to a particular Pila bibractensis cell composition that do not produce medium- and long-chain hydrocarbon during pyrolysis like the ones of Botryococcus braunii. The torbanites composed of this species is often related to a brackish environment, which supposes that the Botryococcus produce cell-walls with long chain molecules, like isoprenoid algaenan, to stabilize their osmotic pressure (Killops and Killops, 2005). These molecules would then derive into medium- and heavy-paraffins during pyrolysis. As, the Autun Permian lake was a freshwater one (Becq-Giraudon et al., 1996; Marteau, 1983), it is likely that Pila bibractensis colonies did not had to produce long chain molecules to protect themselves from brackish environmental conditions.

\section{Conclusions}

Typical lacustrine OM was usually considered to have high HI values, to produce primary fluids with strong concentrations in medium/heavy $n$-alkanes and to be monoenergetic. However, our study shows that these characteristics can be variable within lacustrine oil-shales of a single basin. In Autun oil-shales, unexpectedly low HI values $(<700 \mathrm{mg} / \mathrm{g}$ TOC) for a lacustrine OM are caused by early maturity, a mix phytoplanktonic/bacterial and terrestrial material and/or by the biologic degradation within the water column of phytoplanktonic/bacterial OM. This mixing of organic particles and/or the biodegradation are also responsible for the bito pluri-energetic activation energy diagrams observed in the oil-shales.

Figure 8 presents a sketch of the evolution of the paleoAutun lake during oil-shale deposition. The OM assemblage in oil-shales seem to be controlled by the terrestrial influx and by the level of the lake, which are both controlled by tectonics and climate conditions. Thus, during the Autunian, the decrease of the tectonic activity and the change from a humid climate to a dryer one caused the diminution of the terrestrial OM inputs to the environment and the shallowing of the paleo-Autun lake, which in fine prevented anoxia in bottom waters and, consequently, permitted the biodegradation of lacustrine OM. Consequently, the oldest oil-shale bed (i.e. Igornay) is characterized by significant terrestrial inputs and a dominance of non-degraded phytoplanktonic/bacterial OM (Fig. 8), whereas the youngest bed studied here (i.e. Surmoulin) shows a dominance of biodegraded lacustrine $\mathrm{OM}$ and low proportions of terrestrial particles (Fig. 8). The intermediate oil-shale beds, Lally and Muse, show an alternation of dominating particles between terrestrial and biodegraded lacustrine ones, which is probably the result of a transitional climate marked by succession of dry and wet periods that would have impacted the lake level.

These tectonic and climatic conditions indirectly influenced the $\mathrm{HC}$ distributions of oil-shales samples as they are linked to the $\mathrm{OM}$ assemblage. Thus, samples with no biodegraded-lacustrine $\mathrm{OM}$ display $\left(n-\mathrm{C}_{6}-n-\mathrm{C}_{14}\right) / n-\mathrm{C}_{14+}$ ratios that are anti-correlated with terrestrial particles concentration (Fig. 8). However, pyrolysates originated from biodegraded lacustrine OM, obtained for the first time in this study, show a prominent hump and low $n$-alkanes concentrations.

Finally, the Autun boghead, the latest organic-rich layer of the basin, is characterized by a dominance of Botryococcus of the genus Pila bibractensis, and was likely deposited in an oligotrophic environment, consequence of 

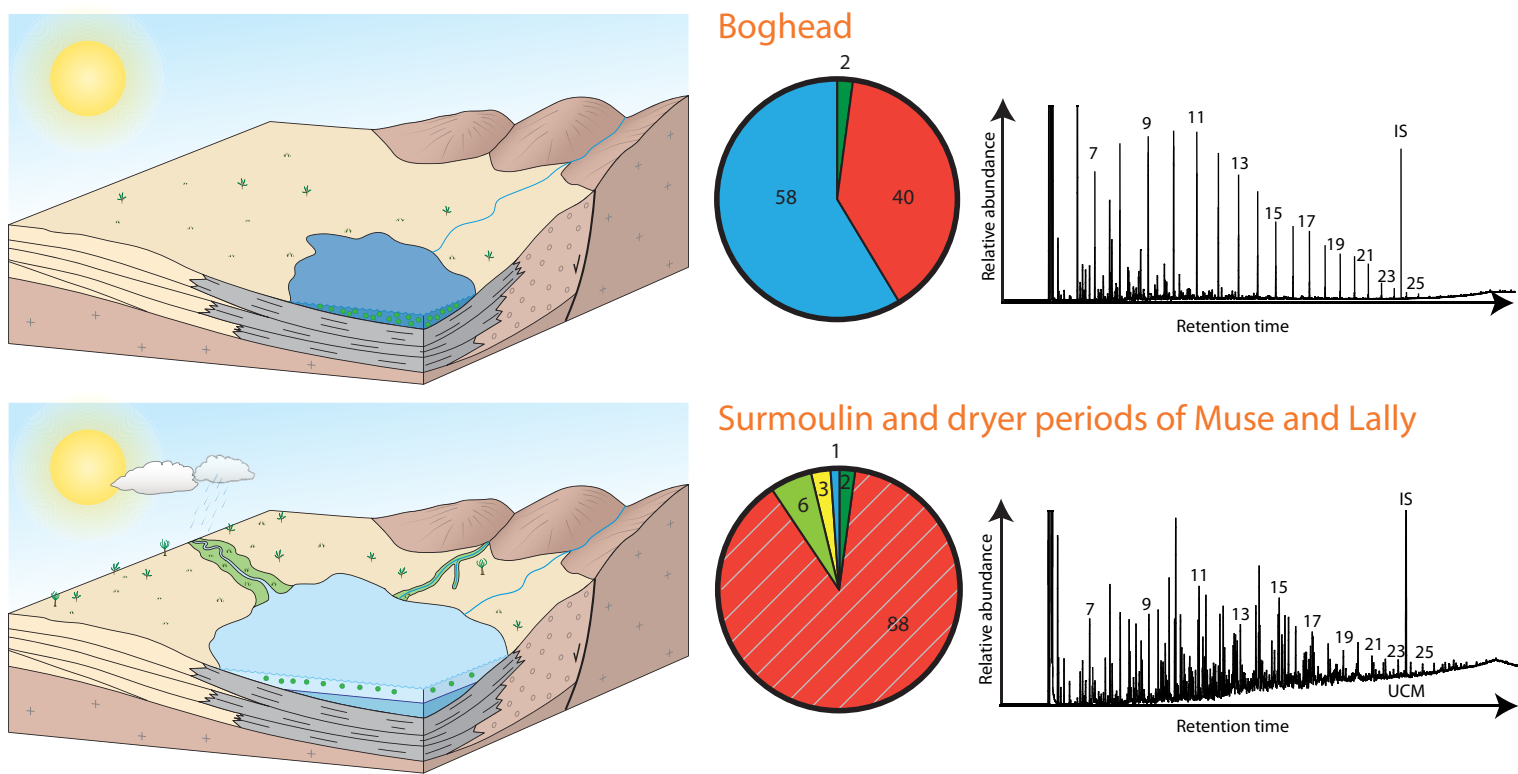

Surmoulin and dryer periods of Muse and Lally
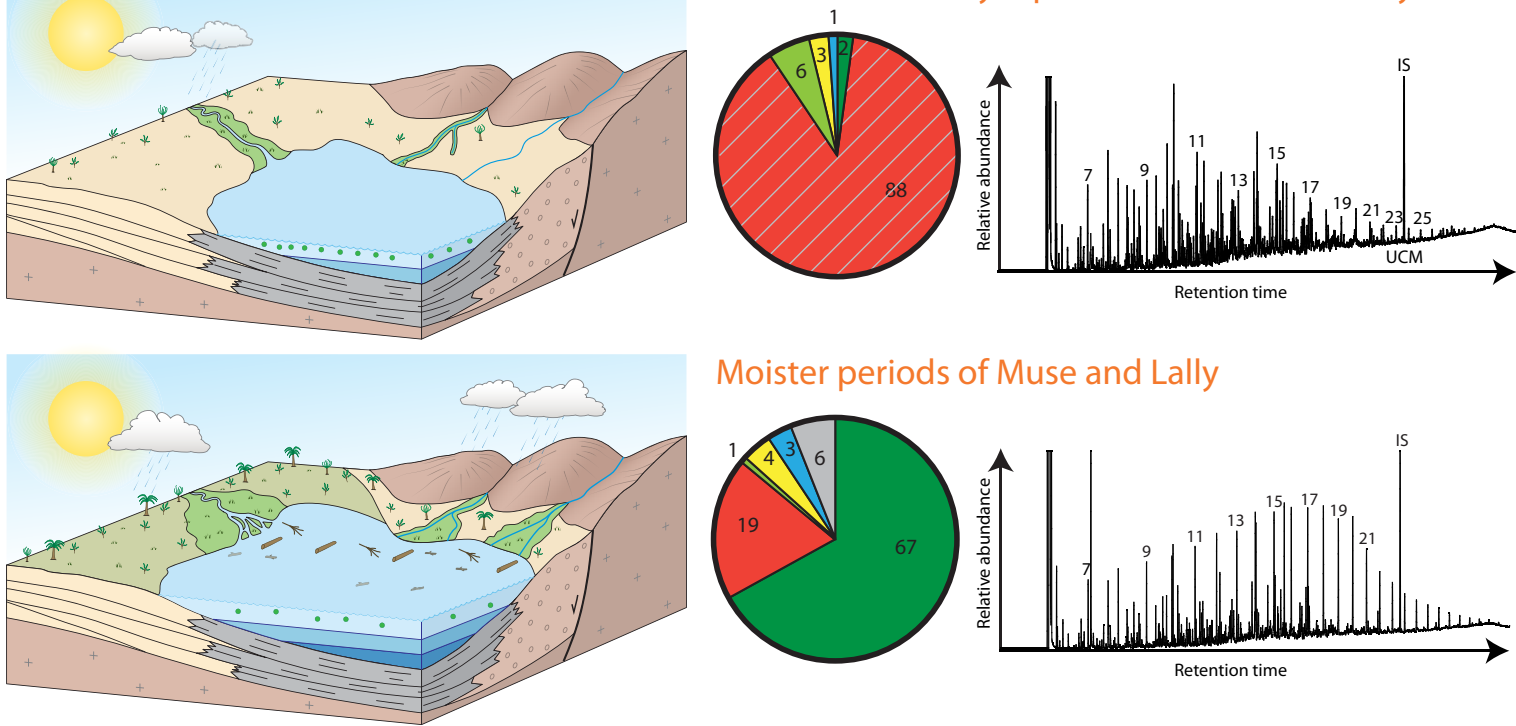

Moister periods of Muse and Lally
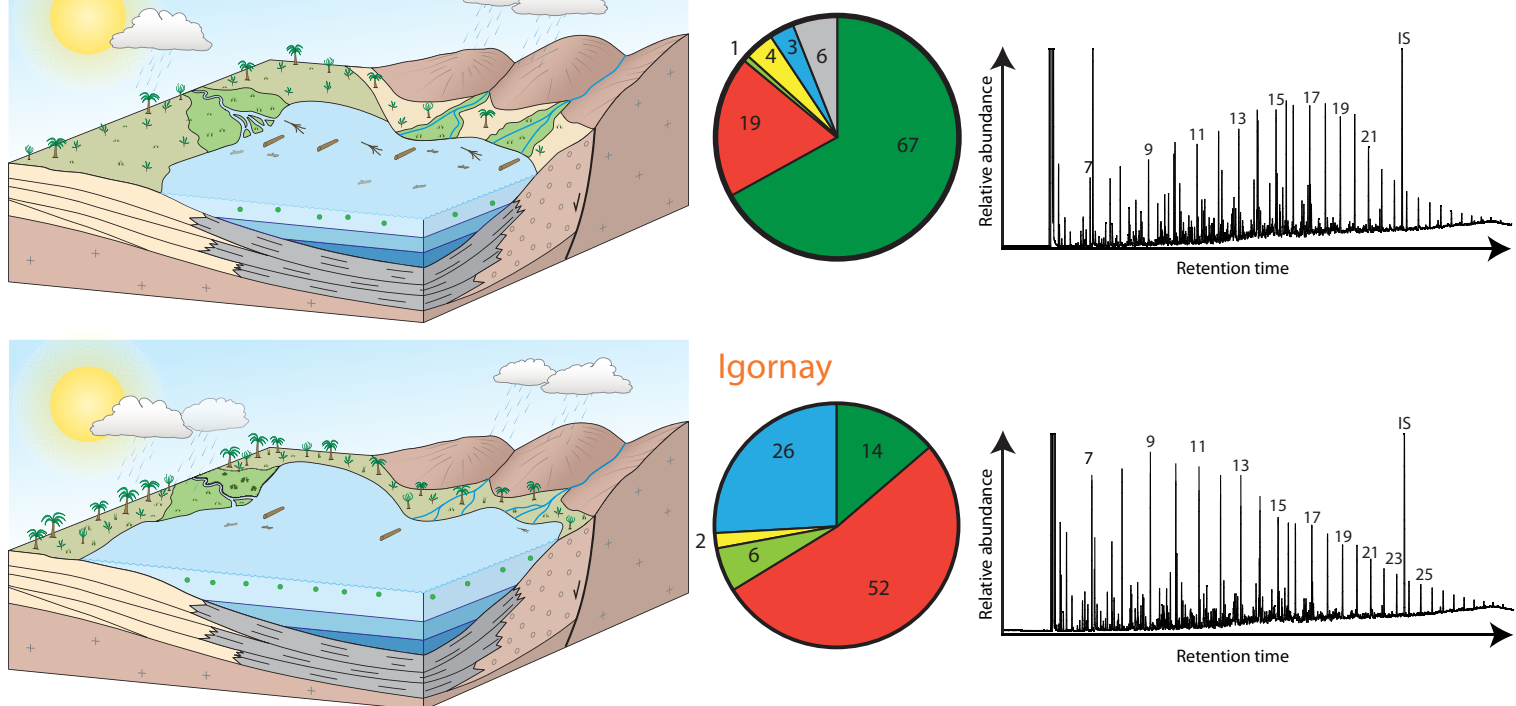

Igornay

redox conditions:
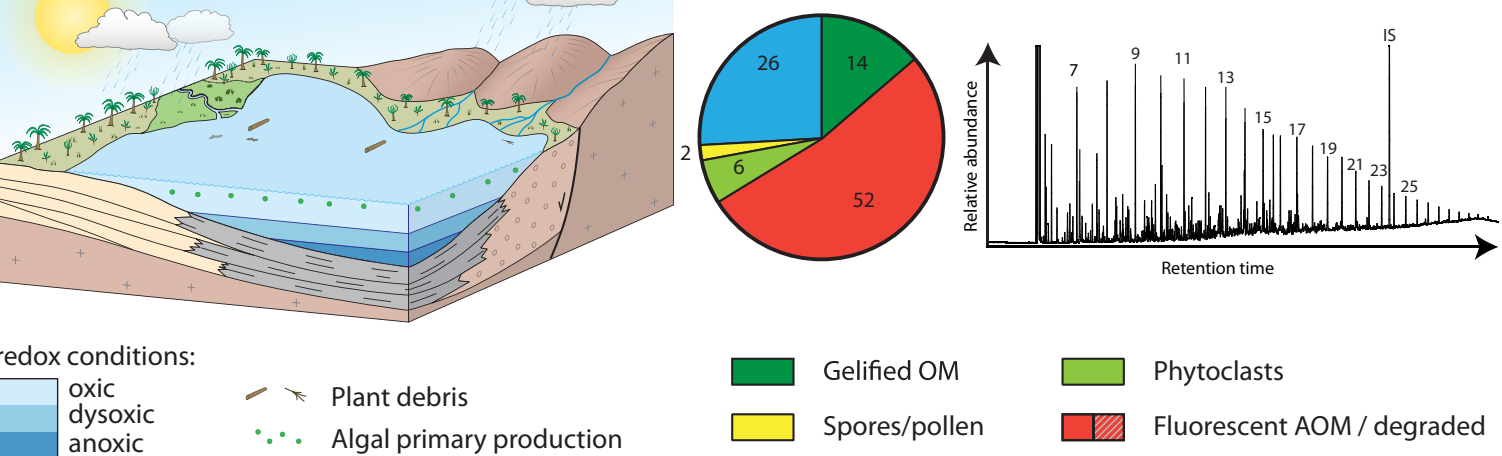

Gelified OM

Phytoclasts

Spores/pollen

Fluorescent AOM / degraded

Botryococcus algea

diffuse AOM

Fig. 8. Palaeogeographic sketch of the Autun lake evolution during oil-shale and boghead deposition compared with OM content and HC distribution. IS = internal standard; UCM: unresolved complex mixture.

the low detrital inputs to the lake. It produces primary fluids strictly dominated by $n$-alkanes $n-\mathrm{C}_{6}$ to $n$ - $\mathrm{C}_{14}$, which is not the case of bogheads composed of Botryococcus braunii (Derenne et al., 1994). This is probably linked to the fact that Pila bibractensis colonies did not had to produce long chain molecules to protect themselves from the environmental conditions as the paleo-Autun lake was not brackish like most of the environment associated with Botryococcus braunii.
Our study thus shows how important it is to characterize source rock formations to make accurate predictions of fluid characteristics that could be trap within the oil-shales in deeper part of a basin, and evaluate the economic potential of an unconventional petroleum system.

Acknowledgments. S.G. thanks Total S.A. for a postdoctoral grant. Eric Legendre (Total S.A.) is acknowledged for scientific discussion. We thank Françoise Champion, Julie 
Gonzalez, Emilie Loustaunau and Didier Massoue (Total S.A.) and Maria Romero-Sarmiento (IFPEN) for their technical support. We would also like to thank D. Chabard (Natural History Museum of Autun) for the core and outcrops access and A. Lethiers for his help on the palaeogeographic sketch. Finally we thank an anonymous reviewer for comments.

\section{References}

Alpern B. 1981. Les schistes bitumineux : constitution, réserves, valorisation. Bull Centres Rech Explor - Prod Elf Aquitaine 5(2): 319-352.

Batten DJ. 1996. Chapter 26A. Palynofacies and paleoenvironmental interpretation. In: Jansonius J, McGregor DC, eds. Palynology: Principles and Applications. Amer Asso Stra Paly Foun 3: 1011-1064.

Becq-Giraudon J-F, Montenat C, Van Den Driessche J. 1996. Hercynian high-altitude phenomena in the French Massif Central: tectonic implications. Palaeogeogr Palaeoclimatol Palaeoecol 122: 227-241.

Behar F, Lorant F, Lewan M. 2008. Role of NSO compounds during primary cracking of a Type II kerogen and a Type III lignite. Org Geochem 39: 1-22.

Behar F, Roy S, Jarvie D. 2010. Artificial maturation of a type I kerogen in closed system: mass balance and kinetic modelling. Org Geochem 41: 1235-1247.

Bertrand C-E, Renault B. 1892. "Pila bibractensis" et le boghead d'Autun. Bull Soc Hist Nat Autun 5: 95.

Bohacs KM, Caroll AR, Neal JE, Mankiewicz PJ. 2000. Lake-basin type, source potential, and hydrocarbon character: an integrated sequence-stratigraphic-geochemical framework. In: GierlowskiKordesch EH, Kelts KR, eds. Lake basins through space and time. AAPG Stud Geol 46: 3-34.

Broutin J, Doubinger J, Farjanel G, Freytet P, Kerp H, Langiaux J, et al. 1990. Le renouvellement des flores au passage CarbonifèrePermien : approche stratigraphique, biologique, sédimentologique. CR Acad Sci Fr 311: 1563-1569.

Broutin J, Chateauneuf J-J, Galtier J, Ronchi A. 1999. L'Autunien d'Autun reste-t-il une référence pour les dépôts continentaux du Permien inférieur d'Europe ? Apport des données paléobotaniques. Geol Fr 2: 17-31.

Burwood R. 1999. Angola: source rock control for Lower Congo coastal and Kwanza Basin petroleum systems. In: Cameron NR, Bare RH, Clure VS, eds. The Oil and Gas Habitats of the South Atlantic. Geol Soc, London, Spec Publ 153: 181-194.

Burwood R, Leplat P, Mycke B, Paulet J. 1992. Proceedings of the 15 th International meeting on organic geochemistry rifted margin source rock deposition: a carbon isotope and biomarker study of a West African lower cretaceous "Lacustrine" section. Org Geochem 19: 41-52.

Chateauneuf JJ, Farjanel G. 1989. Synthèse géologique des bassins permiens français. Mém BRGM 128: 288.

Chateauneuf JJ, Disnar JR, Farjanel G, Feys R, Greber C, Hery B, et al. 1982. Inventaire des séries uranifères d'Europe : Permien et autres milieux continentaux. Orléans: Rap BRGM 82 SGN 124 GEO, 124 p.

Delfour J, Arène J, Clozier L, Feys R, Delance JH. 1991. Carte géologique de France (1/50 000), feuille 551: Autun. $1^{\text {ère }}$ édition. Orléans : BRGM. Notice explicative par Delfour J, et al. (1991), 88 p.

Derenne S, Largeau C, Behar F. 1994. Low polarity pyrolysis products of Permian to recent Botryococcus-rich sediments: first evidence for the contribution of an isoprenoid algaenan to kerogen formation. Geochim Cosmochim Acta 58: 3703-3711.
Durand B, Nicaise D. 1980. Procedure of kerogen isolation. In: Durand B, ed. Insoluble Organic Matter From Sedimentary Rocks. Paris : Éditions Technip, pp. 13-34.

Espitalié J, Deroo G, Marquis F. 1985. La pyrolyse Rock-Eval et ses applications, deuxième partie. Rev Inst Fr Pét 40: 563-579.

Fritsche W, Hofrichter M. 2000. Aerobic degradation by microorganisms. In: Klein J, ed. Biotechnology. New York: John Wiley \& Sons, vol. 11b, pp. 146-164.

Furmann A, Mastalerz M, Brassell SC, Pedersen PK, Zajac NA, Schimmelmann A. 2015. Organic matter geochemistry and petrography of Late Cretaceous (Cenomanian-Turonian) organic-rich shales from the Belle Fourche and Second White Specks formations, westcentral Alberta. Canada Org Geochem 85: 102-120.

Gaglianone PC, Trindade LAF. 1988. Caracterização geoquímica dos óleos da Bacia do Recôncao. Geoch Brasi 2: 15-39.

Gall JC. 1979. Paléoécologie et paléoenvironnements de quelques schistes bitumineux. In: Busson G, ed. Lyon: Doc Lab Geol Fac Sci Lyon, vol. 75, pp. 19-31.

Galtier J. 1980. Les végétaux silicifiés du Permien d'Autun : analyse quantitative et interpretation possible. Bull Soc Hist Nat Autun 95: 35-39.

Gand G, Châteauneuf JJ, Durand M, Chabard D, Passaqui JP. 2007. Early Permian Continental environments in the Autun basin. In: Gand G, Châteauneuf JJ, Durand M, Chabard D, Passaqui JP, eds. Pre-symposium fieldtrip guide: Autun. Paris: Publ ASF 56.

Harris NB, Freeman KH, Pancost RD, White TS, Mitchell GD. 2004. The character and origin of lacustrine source rocks in the Lower Cretaceous synrift section, Congo Basin, west Africa. AAPG Bull 88(8): 1163-1184.

Heyler D. 1969. Vertébrés de 1'Autunien de France. Cah. Paléont. Paris : CNRS, 255 p.

Jarvie DM. 2012. Shale resource systems for oil and gas: Part 2 - Shaleoil resource systems. In: Breyer JA, ed. Shale reservoirs - Giant resources for the 21st century. AAPG Memoir 97: 89-119.

Johnson TC, Halfman JD, Rosendahl BR, Lister GS. 1987. Climatic and tectonic effects on sedimentation in a rift-valley lake; evidence from high-resolution seismic profiles, Lake Turkana, Kenya. Geol Soc Am Bull 98: 439-447.

Katz BJ. 1995. Lacustrine source rock systems - is the Green River Formation an appropriate analog? Geologiya i Geofizika 36: 26-41.

Kawamura K, Ishiwatari R, Ogura K. 1987. Early diagenesis of organic matter in the water column and sediments: microbial degradation and resynthesis of lipids in Lake Haruna. Org Geochem 11: 251-264.

Killops SD, Killops VJ. 2005. An Introduction to Organic Geochemistry, 2nd ed. Oxford: Wiley-Blackwell, 394 p.

Largeau C, Derenne S, Casadevall E, Kadouri A, Sellier N. 1986. Pyrolysis of immature Torbanite and of the resistant biopolymer (PRB A) isolated from extant alga Botryococcus braunii. Mechanism of formation and structure of torbanite. Org Geochem 10: 1023-1032.

Lebedel V. 2009. Étude sédimentologique des variations du potential pétroligène des schistes bitumineux de l'Autunien du bassin d'Autun. Mémoire de Master. Univ. Pierre et Marie Curie, 61 p.

Lewan MD, Ruble TE. 2002. Comparison of petroleum generation kinetics by isothermal hydrous and nonisothermal open-system pyrolysis. Org Geochem 33: 1457-1475.

Ma P, Wang L, Wang C, Wu X, Wei Y. 2015. Organic-matter accumulation of the lacustrine Lunpola oil shale, central Tibetan Plateau: Controlled by the paleoclimate, provenance, and drainage system. Int J Coal Geol 147-148: 58-70.

Marteau P. 1983. Le bassin permo-carbonifère d'Autun : stratigraphie, sédimentologie et aspects structuraux. Ph.D. thesis, Univ. de Dijon. Document du BRGM, 64, 193 p. 
Mayer-Eymar C. 1881. Classification internationale des terrains sédimentaires. Archi Soc Géol Fr 1-15.

Meyers PA, Eadie BJ. 1993. Sources, degradation and recycling of organic matter associated with sinking particles in Lake Michigan. Org Geochem 20: 47-56.

Meyers PA, Ishiwatari R. 1993. Lacustrine organic geochemistry - an overwiew of indicators of organic matter sources and diagenesis in lake sediments. Org Geochem 20: 867-900.

Parrish JT. 1993. Climate of the Supercontinent Pangea. J Geol 101: 215-233.

Perlmutter MA, Matthews MD. 1990. Global cyclostratigraphy-a model. In: Cross TA, ed. Quantitative Dynamic Stratigraphy: Englewood Cliffs. New Jersey: Prentice Hall, pp. 233-260.

Peters K, Walters C, Moldowan M. 2005. The biomarker guide: Biomarkers and Isotopes in the Petroleum Exploration and Earth History. Cambridge: Cambridge University Press, vol. 2, 680 p.

Powell TG. 1986. Petroleum geochemistry and depositional setting of lacustrine source rocks. Mar and Pet Geol 3: 200-219.

Ruble TE, Lewan MD, Philp RP. 2001. New insights on the Green River petroleum system in the Uinta basin from hydrous pyrolysis experiments. AAPG Bull 85(8): 1333-1371.

Schneider JW, Körner F, Roscher M, Kroner U. 2006. Permian climate development in the northern peri-Tethys area - The Lodève basin, French Massif Central, compared in a European and global context. Palaeogeogr Palaeoclimatol Palaeoecol 240: 161-183.

Sebag D, Copard Y, Di-Giovanni C, Durand A, Laignel B, Ogier S, et al. 2006. Palynofacies as useful tool to study origins and transfers of particulate organic matter in recent terrestrial environments: Synopsis and prospects. Earth-Sci Rev 79: 241-259.

Shanahan TM, Overpeck JT, Wheeler CW, Beck JW, Pigati JS, Talbot MR, et al. 2006. Paleoclimatic variations in West Africa from a record of late Pleistocene and Holocene lake level stands of Lake Bosumtwi, Ghana. Palaeogeogr Palaeoclimatol Palaeoecol 242: 287-302.

Staplin FL. 1977. Interpretation of thermal history from color of particulate organic matter, a review. Palynology 1: 9-18.

Tegelaar EW, Noble RA. 1994. Kinetics of hydrocarbon generation as a function of the molecular structure of kerogen as revealed by pyrolysis-gas chromatography. Org Geochem 22: 543-574.

Teichmüller M, Durand B. 1983. Fluorescence microscopical rank studies on liptinites and vitrinites in peat and coals, and comparison with results of the Rock-Eval pyrolysis. Int J Coal Geol 2: 197-230.

Teichmüller M, Wolf M. 1977. Application of fluorescence microscopy in coal petrology and oil exploration. J Microsc 109(1): 49-73.

Tissot BP, Welte DH. 1984. Petroleum Formation Occurence, second edn. Berlin: Springer-Verlag, 699 p.

Tribovillard N, Algeo T, Lyons TW, Riboulleau A. 2006. Trace metals as paleoredox and paleoproductivity proxies: an update. Chem Geol 232: 12-32.

Tyson RV. 1995. Sedimentary organic matter. Organic Facies and Palynofacies. London: Chapman and Hall, 615 p.

Ungerer P, Pelet R. 1987. Extrapolation of the kinetics of oil and gas formation from laboratory experiments to sedimentary basins. Nature 327: 52-54.

Wenger LM, Isaksen GH. 2002. Control of hydrocarbon seepage intensity on level of biodegradation in sea bottom sediments. Org Geochem 33: 1277-1292.

Ziegler AM. 1990. Phytogeographic patterns and continental configurations during the Permian period. In: McKerrow WS, Scotese CR, eds. Palaeozoic Palaeogeography and Biogeography. Geol Soc, London, Mem 12: 363-379.

Cite this article as: Garel S, Behar F, Schnyder J, Baudin F. 2017. Palaeoenvironmental control on primary fluids characteristics of lacustrine source rocks in the Autun Permian Basin (France), Bull. Soc. géol. Fr. 188: 29. 